\title{
Lip Pain, CTCAE 5.0
}

National Cancer Institute

\section{Source}

National Cancer Institute. Lip Pain, CT CAE 5.0. NCI Thesaurus. Code C146761.

A disorder characterized by a sensation of marked discomfort of the lip. 